\title{
Physicochemical Changes during Vermicomposting of Water Hyacinth (Eichhornia crassipes) and Grass Clippings
}

\begin{abstract}
Abdullah Adil Ansari and Jerome Rajpersaud
Department of Biology, University of Guyana, Georgetown 05924, Guyana

Correspondence should be addressed to Abdullah Adil Ansari, abdullahadilansari@gmail.com

Received 17 December 2011; Accepted 9 January 2012

Academic Editors: T. J. Cutright and Z. He

Copyright ( $\odot 2012$ A. A. Ansari and J. Rajpersaud. This is an open access article distributed under the Creative Commons Attribution License, which permits unrestricted use, distribution, and reproduction in any medium, provided the original work is properly cited.

The present study was aimed at large scale processing of organic waste (grass-T1, water hyacinth-T2, water hyacinth + grass-T3) in three different combinations through biodung and vermicomposting. The results indicated that the pre-digestion of organic waste through anaerobic and aerobic decomposition was most effective in T3. The temperature of the biodung units rose to a maximum of $37.5 \pm 1.5^{\circ} \mathrm{C}$ and then declined gradually to a constant temperature of $35.25 \pm 1.75^{\circ} \mathrm{C}$, bringing about reduction of organic waste free from harmful microbes. The temperature during the process of vermicomposting was observed to be $28.26 \pm 2.19^{\circ} \mathrm{C}$ in $\mathrm{T} 1$ followed by $27.31 \pm 0.80^{\circ} \mathrm{C}$ in $\mathrm{T} 2$ and $26.94 \pm 0.68^{\circ} \mathrm{C}$ in T3. The $\mathrm{pH}$ in three units was near neutral $(6.81 \pm 0.18)$. C: $\mathrm{N}$ ratio was reduced to the required level $(12.41 \pm 3.71)$. Vermicomposting in T3 resulted in high productivity of vermicompost followed by T2 and T1 which was due to preferential palatability of earthworms Eisenia foetida towards mixed composting material in T3. The results indicated that the vermicompost is highly rich in nutrient and the percentages of these nutrients in the compost vary as the process proceeded until their ideal concentrations for the promotion of plant growth reached.
\end{abstract}

\section{Introduction}

In Guyana, major drainage and irrigation water ways are plagued by large amounts of aquatic weeds, a major one being the water hyacinth (Eichhornia crassipes) which creates a problem of clogging because its petioles have air- filled bladders called arenchyma. In addition, transpiration from dense mats of water Hyacinth can drain a water way at an incredible rate; a trench covered with E. crassipes loses water almost eight times faster than uncovered surfaces. This creates yet another problem of excessive loss of water during the dry seasons. The piling of grass clippings from playfields and lawns is usually an eye sore, since their bulk fills limited landfill sites quickly and takes a long time to decay. These problems can be solved by converting the above into useful organic fertilizer for agricultural use [1].

Vermicomposting is the process of producing vermicompost by utilizing earthworms to turn organic waste into highquality compost that consists mainly of worm cast in addition to decayed organic matter; thus, it serves as a nutrientrich natural fertilizer and soil conditioner $[2,3,13,14]$.
The earthworms, Eisenia foetida and Lumbricus rubellus, used in vermicomposting occupy a different ecological niche (epigeics), living near the surface of the earth where there is a high concentration of organic matter; they are especially adapted to special conditions in rotting vegetation, compost, and manure pile [5].

Vermicompost and vermiculture associated with other biological inputs have been actually used to grow vegetables and other crops with much success [6-8]. It has been found to be economically productive. Case studies conducted in several villages in Uttar Pradesh, India (1999-2000) with several biofertilizers such as Nadep compost, vermicompost, biodynamic preparations 500 , cow pat pit and liquid manure on paddy, wheat, and potato indicated that when biofertilizers are applied in combinations, they have a positive impact on the yield parameters. The pest defender ratios were found to be less in organic fields compared to fields that were treated with chemical fertilizers. This evidence strongly advocates the concept of organic farming [9]. Thus, organic farming is a self-sustained and economical system where biofertilizers can be produced using agrowaste, with 
less resource management. Additionally, organic farming is ecologically safe and economically viable [9].

On the regional scene, at the demonstration and training center of the CARDI Jamaica Unit, a greenhouse study has shown enhanced pepper seedlings growth when treated with low levels of vermicompost compared to thermophilic compost, commercial, and traditional potting mixtures [10]. In Guyana, a recent investigation into the recycling of sugar cane bagasse and rice straw to produce compost, using vermitechnology and using the compost on Phaseolus vulgaris, concluded that the physiochemical properties of the rice straw and the combinations (bagasse with rice straw) were beneficial and enhanced growth and yield of Phaseolus vulgaris. The soil chemical analysis also indicated improvement in nutrient content [11].

\section{Materials and Method}

Research work was carried out during 2006-2007 at the University of Guyana campus aiming at recycling solid organic waste (water hyacinth and grass) from urban and rural areas. This recycling was done by employing vermitechnology in established units. This process involved initial biodung composting (predigestion) of fresh waste followed by vermicomposting. The study concentrated on organic waste such as grass clippings, water hyacinth, and cattle manure, which was composted using vermitechnology within sixty days to obtain vermicompost. The temperature was monitored daily from the start of biodung composting until the transfer to the vermicomposting tanks. A standard nutrient status of vermicompost with reference to $\mathrm{pH}$, electric conductivity, organic carbon and nitrogen, potassium and phosphorus, was recorded. Potential status of vermicompost as biofertilizer generated from solid organic waste was assessed for use in Guyana.

The vermitechnology units were established at University of Guyana campus. Chemical analysis of the vermicompost was done at the Guyana Sugar corporation Central Laboratory, situated at L.B.I., on the East Coast of Demerara. A culture room with three tanks was established, and epigeic earthworms were inoculated with paddy straw and cow dung. Eisenia foetida was used in the experiment. Biodung composting was carried out according to the following guidelines:

(1) cow dung slurry was made by adding water to cow dung in a ratio of $6: 3$ and stirring mixture;

(2) cow dung slurry was added layer after layer to the organic materials which were soaked with water;

(3) the heaps were then covered with tarpaulin for thirty days after an initial temperature was taken;

(4) the layers were turned every ten days;

(5) the temperatures were recorded every three days from the time of settingup the biodung units.

Three of the vermicomposting units were constructed with cement, each having dimensions of 5 feet $\times 2.5$ feet for bulk production of vermicompost from predigested organic matter. Zinc shed was constructed above the units for shade. Each of vermicomposting units 1, 2, and 3 comprised of several layers. The first layer starting from the bottom was packed with 2-3 inches of pebbles and broken bricks, the second layer had sand, the third had 3 inches of soil. In the fourth layer, cattle dung was added, and here, the earthworms were inoculated, 100-200 earthworms per square meter of vermibed. The predigested (biodung) grass, water hyacinth, water hyacinth + grass were added to vermiunits, 1,2 , and 3 , respectively. This was followed by a fifth layer of the predigested (biodung) organic waste. The final layer acted as a mulch to prevent evaporation. This comprised of grass and dry leaves. The surfaces of the entire vermin pits were covered with tarpaulin, which were kept moist by spraying water daily. When all the organic matter was converted to vermicompost in 60 days, it was harvested. Watering was stopped for a week so that the earth worms can move down. The vermi compost after harvested was sieved through a $3 \mathrm{~mm}$ sieve. In order to assess the physicochemical changes during the process, samples were taken from each unit every 10-12 days after the predigested matter was added.

The physicochemical analysis of vermicompost and raw organic matter was carried out according to standard guidelines [12]. The samples were then taken and placed to air-dry and then ground for chemical analysis, together with the raw materials (water hyacinth, grass, and a mixture of the two) using standard procedure for the following: $\mathrm{pH}, \mathrm{EC}$, organic carbon, total kjeldahl nitrogen, available phosphate, and potash.

\section{Results and Discussion}

Table 1 indicated that the maximum productivity in unit 3 (T3) in which the organic waste was in the form of water hyacinth + grass clippings. This is due to greater earthworm activity in (T3) and their preferred palatability of mixed organic waste during the processes of vermicomposting. The mass of the organic material transferred to vermitech unit differed significantly from the mass of vermicompost harvested. The ingested organic material is macerated mixed with ingested soil material passed through the gut and is excreted as casts, with most of it very little changed chemically, but finely ground [2-4, 9].

Partial biodung composting in T2 and T3 was carried out for the period of 3 weeks and transferred to respective vermicomposting units, whereas in T1 it was continued to 6 weeks. The temperature study showed that there were twopeak rise of temperature during partial biodung composting in T1 whereas single peak in T2 and T3 (Figure 1). The partial biodung compost obtained served as a good organic material for the earthworms to recycle and produce vermicompost. The temperature increase brings about killing of harmful microbes. The process of biodung composting involves partially aerobic and partially anaerobic process. This reduces the bulk of organic waste to one-third of the volume. The cattle dung solution serves the purpose of providing inoculum of microbes which carry out degradation of organic waste. During the process of biodung composting, mesophilic flora predominates with their metabolic activity 
TABle 1: Harvest data (vermicompost).

\begin{tabular}{lccc}
\hline Units (composition) & T1 (grass) & T2 (water hyacinth) & T3 (grass + water hyacinth) \\
\hline Initial mass (kg) & 230 & 210 & 105 \\
Transfer to vermitech unit $(\mathrm{kg})$ & 120 & 120 & 80 \\
Conversion rate $(\%)$ & $\mathbf{5 2 . 1 7}$ & $\mathbf{5 7 . 1 4}$ & $\mathbf{7 6 . 1 9}$ \\
Harvested vermicompost $(\mathrm{kg})$ & 60 & 65 & 48 \\
Dried vermicompost (kg) with 40 percent moisture & 38 & 41 & 32 \\
Productivity of vermicompost (\%) & $\mathbf{3 1 . 6 7}$ & $\mathbf{3 4 . 1 7}$ & $\mathbf{4 0 . 0 0}$ \\
\hline
\end{tabular}

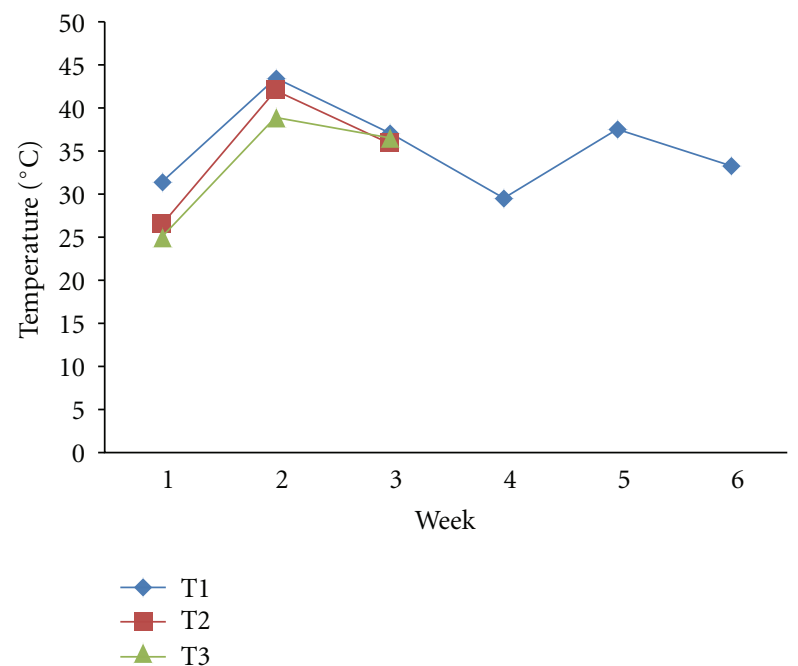

Figure 1: Temperature $\left({ }^{\circ} \mathrm{C}\right)$ changes during biodung composting for transfer to vermicomposting.

resulting in the increase in temperature of the organic waste. They are replaced by thermophilic organisms which survive at temperatures greater than $45^{\circ} \mathrm{C}$ to facilitate composting. When the temperature falls, mesophilics become active again. The changes in the microflora like bacteria, actinomycetes, and fungi during composting have been well studied $[1,4,13,14]$.

Temperature also observed during the process of vermicomposting in the three vermicomposting units was recorded to be $28.26 \pm 2.19^{\circ} \mathrm{C}$ in $\mathrm{T} 1$ followed by $27.31 \pm 0.80^{\circ} \mathrm{C}$ in $\mathrm{T} 2$ and $26.94 \pm 0.68^{\circ} \mathrm{C}$ in $\mathrm{T} 3$. The temperature study showed that fluctuation was restricted to \pm 2.34 (T1), \pm 0.73 (T2), and \pm 0.83 (T3) (Figure 2).

The initial materials, water hyacinth (T2), mixture of water hyacinth and grass (T3), were initially at a neutral $\mathrm{pH}$, with the exception of grass (T1) which was extremely mildly acidic, when they were added to the vermicompost units (Figure 3). The $\mathrm{pH}$ for all fluctuated between 5 and 8 until it was almost neutral on the day 60 , when the compost was harvested. In T3, the percentage change in $\mathrm{pH}$ is minimal due to the moisture content of the water hyacinth; thus, the water released tends to neutralize the $\mathrm{pH}$ of the vermicompost. Generally in all the units, there was a temporary rise in $\mathrm{pH}$. Earthworms contribute several nutrients in the form of nitrogenous wastes. Ammonia which forms a large portion

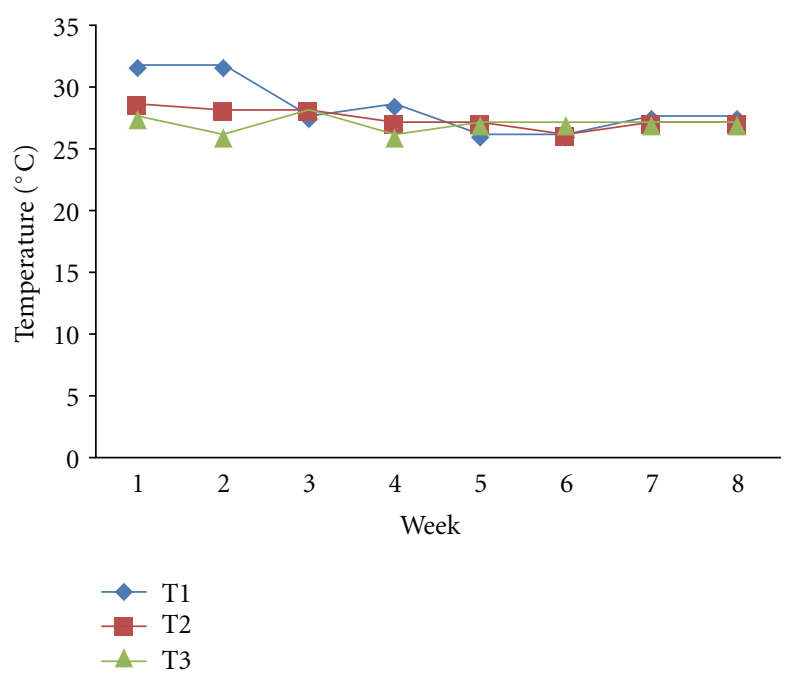

Figure 2: Temperature $\left({ }^{\circ} \mathrm{C}\right)$ changes during the period of vermicomposting.

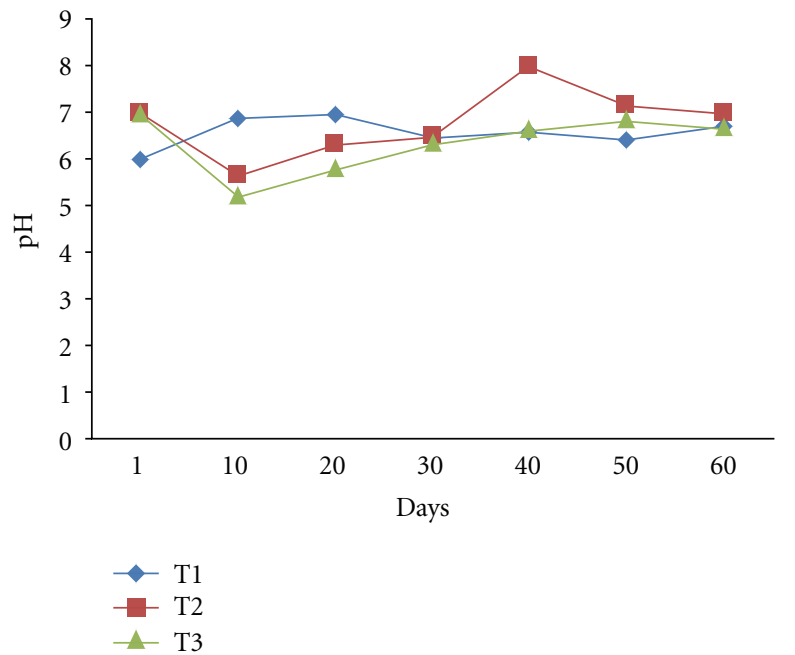

FIGURE 3: pH changes during composting process (60 days).

of nitrogenous matter excreted by earthworms may cause a temporary rise in $\mathrm{pH}[2,3,15]$. The $\mathrm{pH}$ regulates the rate of dissolution of substances, and thus absorption. Soil $\mathrm{pH}$ is one of the most important soil properties that affect the availability of nutrients. Macronutrients tend to be less 


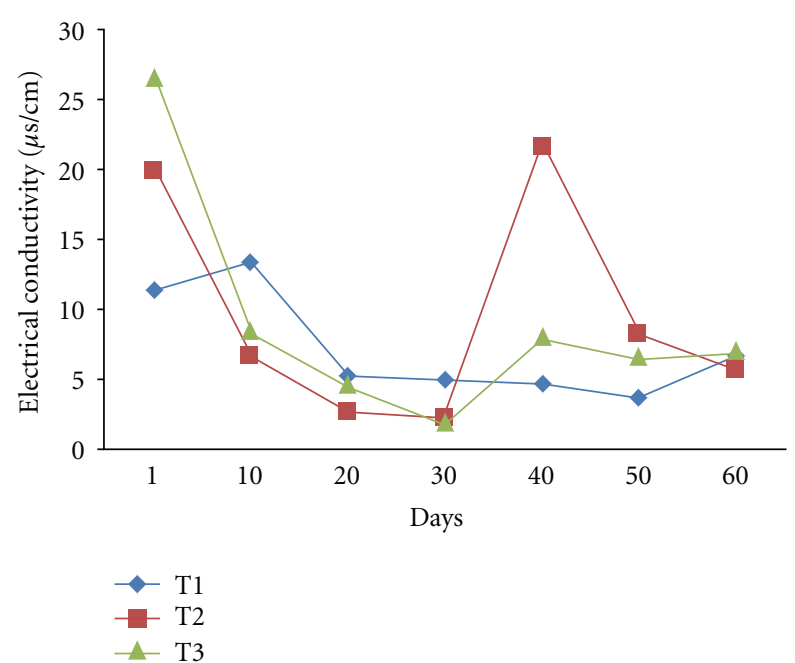

FIGURE 4: Electrical conductivity $(\mu \mathrm{s} / \mathrm{cm})$ changes during composting process (60 days).

available in soils with low $\mathrm{pH}$, and micronutrients tend to be less available in soils with high $\mathrm{pH}$ [16]. Thus, it is necessary for the compost to have an ideal $\mathrm{pH}$ when added to the soils so as to promote absorption of nutrients [17].

The electrical conductivity for T2 and T3 decreased steadily up to day 30 and increased sharply on day 40 , followed by a gradual decrease. A similar pattern was observed for $\mathrm{T} 1$, but there was an initial increase in EC, followed by a steady decrease. The percentage change for T2 and T3 differed slightly, but there was a significant percentage change for T1 (Figure 4). Generally, there was a significant decrease in EC of the initial materials as the vermicomposting process proceeded, until a lower EC was attained, which is ideal for plant growth. With a low EC, the organic fertilizers release the mineral salts slowly, which is sufficient for plant growth $[11,18]$.

There was a decrease in organic carbon for all three units with gradual decrease at later stage of vermicomposting process. A decrease in carbon is an indicator of enhanced decomposition [19-22]. This also explains why the percentage changes were so large for T1, T2, and T3 (Figure 5). The significant percentage change indicated that earthworms accelerated the decomposition of the organic matter. Carbon is needed by the plants because it forms the basis for energy source for the composting process. Carbon is a major component of organic molecules, which are the building blocks of all organisms $[3,11]$.

There was a sharp increase of nitrogen in $\mathrm{T} 1$ and $\mathrm{T} 3$ followed by a decrease, whereas there was a decrease in nitrogen percentage in T2 (Figure 6). This high level of nitrogen during the process of vermicomposting is probably contributed by earthworms through excretion of ammonia along with reduction of organic waste to nitrogen component. The significant reduction in the percentage, nitrogen is probably due to $\mathrm{NH}_{3}$ volatilization, incorporation into earthworm tissues, and leaching into the bedding material. This can also account for the significant percentage change

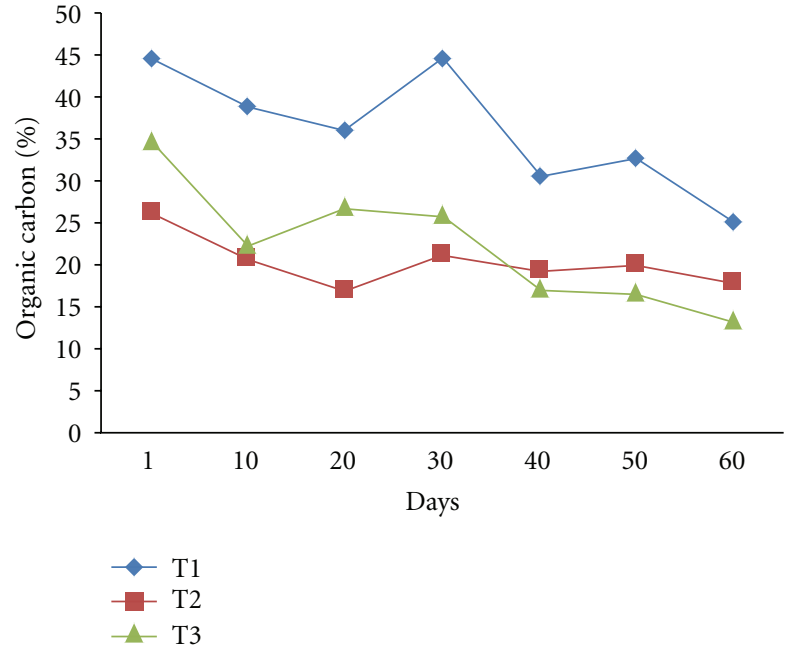

Figure 5: Organic carbon (\%) changes during composting process (60 days).

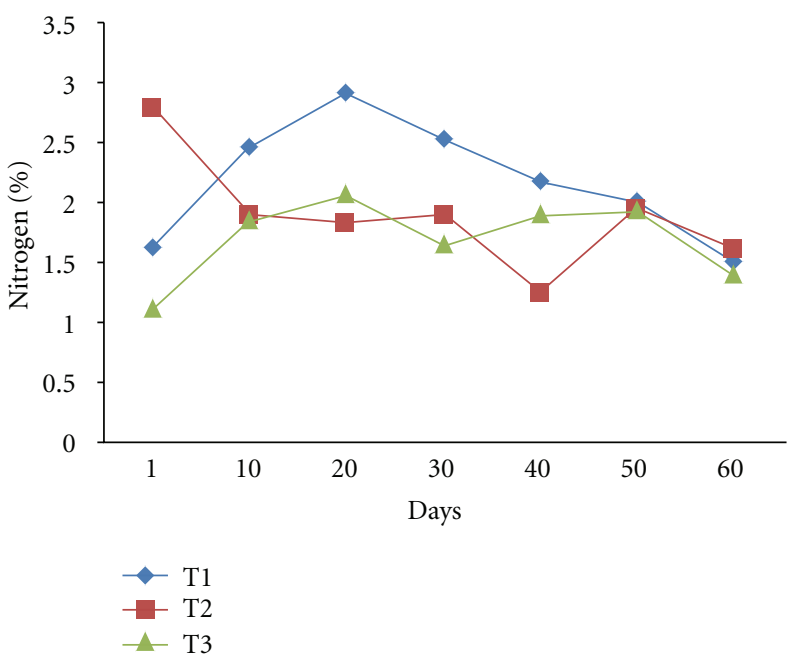

FIGURE 6: Nitrogen (\%) changes during composting process (60 days).

in T3. In $\mathrm{T} 1$ and $\mathrm{T} 2$, there was a negative percent change which was probably as a result of microbial utilization. In $\mathrm{T} 2$, there was a decrease during the first twenty days, and a small increase for the next ten days, followed by a fluctuating pattern.

The general trend of T1, T2, and T3 (Figure 7) shows a decline in carbon nitrogen ratio during the process of litter breakdown and decomposition, and the ratio of $\mathrm{C}: \mathrm{N}$ is progressively brought down, especially through feeding by earthworms to levels when nitrogen can be directly taken up by plants [2]. The nitrogen gets mineralized and is shifted to nucleic acids [3], ammonia, urea, and nitrates; and the carbon is used for respiration by the microbes. The net result is the lowering of the $\mathrm{C}: \mathrm{N}$ ratio during the decomposition process. 
TABle 2: ANOVA (Two-factor without replication).

\begin{tabular}{lcccccc}
\hline \multirow{2}{*}{ Parameter } & \multicolumn{2}{c}{$\mathrm{pH}$} & \multicolumn{2}{c}{ E.C } & \multicolumn{2}{c}{ O.C } \\
& $\mathrm{F}$ & $\mathrm{F}$ crit & $\mathrm{F}$ & $\mathrm{F}$ crit & $\mathrm{F}$ & F crit \\
\hline (Units) & 1.057064 & 3.885294 & 0.482963 & 3.885294 & 39.28112 & 3.885294 \\
Changes (Day 1-60) & 1.403614 & 2.99612 & 3.694872 & 2.99612 & 7.031721 & 2.99612 \\
\hline
\end{tabular}

TABle 3: ANOVA (Two-factor without replication).

\begin{tabular}{|c|c|c|c|c|c|c|}
\hline \multirow{2}{*}{ Parameter } & \multicolumn{2}{|c|}{$\mathrm{N}$} & \multicolumn{2}{|c|}{$\mathrm{P}$} & \multicolumn{2}{|c|}{ K } \\
\hline & $\mathrm{F}$ & F crit & $\mathrm{F}$ & F crit & $\mathrm{F}$ & F crit \\
\hline Units & 1.903015 & 3.885294 & 1.0101664 & 3.885294 & 0.111551 & 3.885294 \\
\hline Changes (Day 1-60) & 0.880498 & 2.99612 & 1.245663 & 2.99612 & 1.718485 & 2.99612 \\
\hline
\end{tabular}

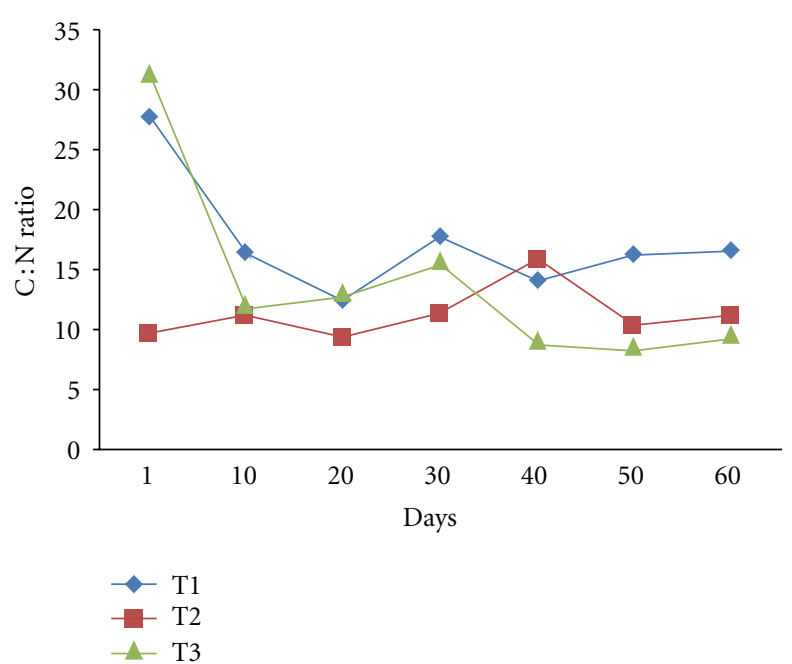

FIGURE 7: C: $\mathrm{N}$ ratio changes during composting process (60 days).

The phosphorus content generally increased significantly during the process (Figure 8). There was a fluctuating pattern in percent changes observed for phosphorus. The general rise in phosphate level from initial materials during the process of vermicomposting is probably due to mobilization and mineralization and mobilization of phosphorus due to bacterial and fecal phosphatase activity of earthworms [23]. The percentage change was significantly high in all three units, because earthworms play a role in the release of phosphates.

There was a fluctuating change in percentage of potassium observed during the vermicomposting process in units $\mathrm{T} 1, \mathrm{~T} 2$, and T3, but at the end of the sixty-day period, a general increase was observed (Figure 9). Potassium forms part of the micronutrient that is boosted by the presence of earthworm activity on organic matter $[4,9,24]$. Organic fertilizers contain the second largest amount of potassium, but these are released at a slow rate in the soil, thus preventing wastage by being washed away $[23,25,26]$. This also accounts for the significant percentage change in all three units.

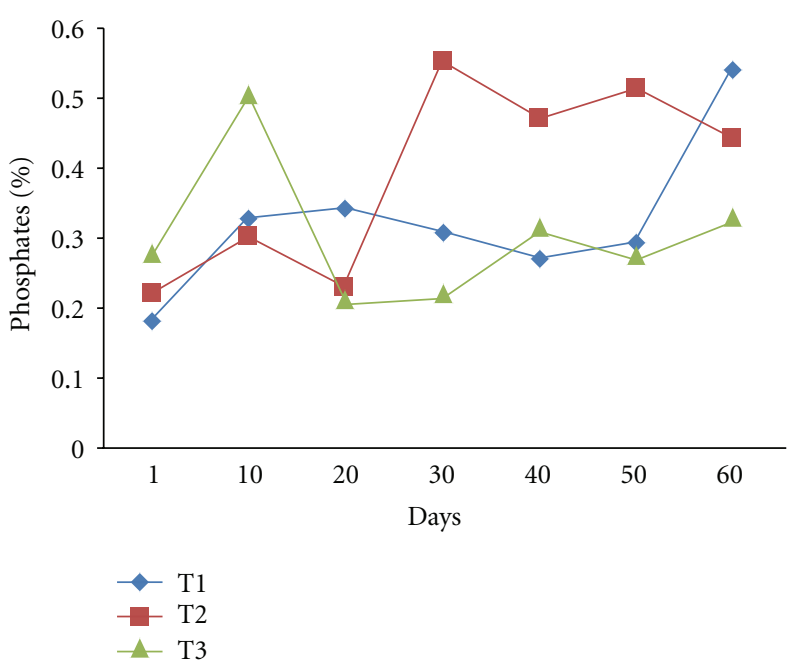

FIGURE 8: Phosphates (\%) changes during composting process (60 days).

Based on the ANOVA test (Tables 2 and 3), the changes in total organic carbon and EC were significant gradual change during the sixty-day period in the individual units for the vermicomposting of grass (T1), water hyacinth, (T2), a mixture of water hyacinth and grass (T3). The difference in total organic carbon between T1, T2, and T3 was also significant indicating the effect of earthworms (Eisenia foetida) on the process of decomposition (vermicomposting). The changes were insignificant for the $\mathrm{pH}$, phosphorus, potassium, and nitrogen.

\section{Conclusion}

This research revealed that the water hyacinth and grass clippings which are all organic matters can be efficiently utilised by earthworms to produce vermicompost. Compost harvested from all three units (T1, T2, and T3) lacked none of the essential nutrients tested for and were present in adequate amounts. Thus, one can recognize that using water hyacinth and grass produces very nutritious biofertilizers. The quantity of any nutrient does not remain constant 


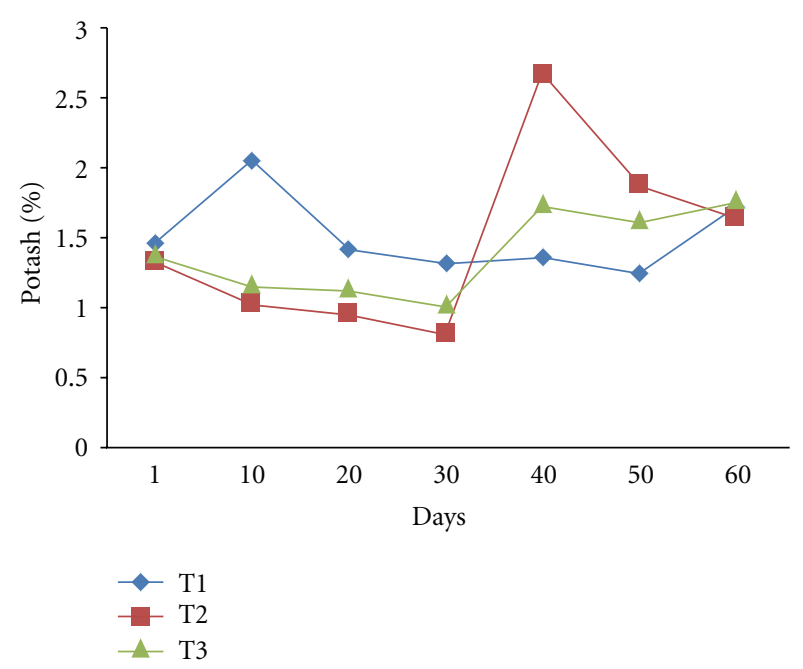

Figure 9: Potash (\%) changes during composting process (60 days).

throughout the process; their levels fluctuate until they reach an ideal level that would promote plant growth. The Harvested compost of T1, T2, and T3 all had nearly the same quantity of nutrients tested for, with the exception of phosphorus and carbon which differed somewhat. This technology can be successfully implemented in Guyana to solve the problem of organic solid waste management.

\section{References}

[1] A. A. Ansari, "Organic waste-reduce, recycle and management through Vermitech," in Urban Planning and EnvironmentStrategies and Challenges, Advance Research Series, India, 2007.

[2] S. A. Ismail, Vermitechnology: The Biology of Earthworms, Orient Longman, Chennai, India, 1997.

[3] S. A. Ismail, The Earthworm Book, Other India Press, Mapusa, Goa, 2005.

[4] A. A. Ansari and S. A. Ismail, "Vermitechnology in organic solid waste management," Journal of Soil Biology and Ecology, vol. 21, 2001.

[5] C. A. Edwards, The Use of Earthworms in the Breakdown and Management of Organic Wastes, CRC Press, Boca Raton, Fla, USA, 2004.

[6] A. A. Ansari, "Effect of Vermicompost on the productivity of Potato (Solanum tuberosum), Spinach (Spinach oleracea) and Turnip (Brassica campestris)," World Journal of Agricultural Sciences, vol. 4, no. 3, pp. 333-336, 2008.

[7] A. A. Ansari, "Soil profile studies during bioremediation of sodic soils through the application of organic amendments (vermiwash, tillage, green manure, mulch, earthworms and vermicompost)," World Journal of Agricultural Sciences, vol. 4, no. 5, pp. 550-553, 2008.

[8] A. A. Ansari, "Effect of vermicompost and vermiwash on the productivity of spinach (Spinacia oleracea), onion (Allium cepa) and potato (Solanum tuberosum)," World Journal of Agricultural Sciences, vol. 4, no. 5, pp. 554-557, 2008.

[9] A. A. Ansari and S. A. Ismail, "A case study on organic farming in uttar pradesh," Journal of Soil Biology and Ecology, vol. 21, 2001.
[10] A. S. Simpson and R. D. Martin, "Studies on Vermiculture and organic vegetable production," University of Technology, Jamaica, 2001.

[11] A. A. Ansari and S. Jaikishun, "Vermicomposting of sugarcane bagasse and rice straw and its impact on the cultivation of Phaseolus vulgaris L. in Guyana, South America," Journal of Agricultural Technology, vol. 7, no. 2, pp. 225-234, 2011.

[12] F. Homer, "Soil Analysis Manuel. Central Analytical and Environmental Monitoring Services," Agriculture Research Department, LBI, Guyana, 2003.

[13] A. A. Ansari, "Worm powered environmental biotechnology in organic waste management," International Journal of Soil Science, vol. 6, no. 1, pp. 25-30, 2011.

[14] A. A. Ansari, "Vermitech: an innovation in organic solid waste management," Journal of Sustainable Development and Environmental Protection, vol. 1, no. 1, pp. 107-113, 2011.

[15] C. A. Edwards and P. J. Bohlen, Biology and Ecology of Earthworms, Chapman and Hall, London, UK, 3rd edition, 1996.

[16] C. A. Edwards and N. Q. Arancon, "The use of earthworms in the breakdown of organic waste to produce vermicomposts and animal protein," in Earthworm Ecology, C. A. Edwards, Ed., pp. 345-438, CRC Press, Boca Raton, Fla, USA, 2nd edition, 2004.

[17] S. Suthar, "Vermicomposting potential of Perionyx sansibaricus (Perrier) in different waste materials," Bioresource Technology, vol. 98, no. 6, pp. 1231-1237, 2007.

[18] A. A. Ansari and K. Sukhraj, "Effect of vermiwash and vermicompost on soil parameters and productivity of okra (Abelmoschus esculentus) in Guyana," African Journal of Agricultural Research, vol. 5, no. 14, pp. 1794-1798, 2010.

[19] P. J. Stoffella and B. A. Kahn, "Compost Utilization in Horticultural Cropping Systems," London, UK, 2000.

[20] S. Kaviraj and S. Sharma, "Municipal solid waste management through vermicomposting employing exotic and local species of earthworms," Bioresource Technology, vol. 90, no. 2, pp. 169173, 2003.

[21] P. K. Agarwal, A. Choudhary, A. Prakash, and B. N. Johri, "Bacterial diversity in a bagasse based compost prepared for the cultivation of edible mushrooms Agaricus bisporus," Journal of Agricultural Technology, vol. 7, no. 5, pp. 1303-1311, 2011.

[22] R. Kumar and Shweta, "Removal of pathogens during vermistabilization," Journal of Environmental Science and Technology, vol. 4, no. 6, pp. 621-629, 2011.

[23] A. A. Ansari and S. A. Ismail, "Reclamation of sodic soils through vermitechnology," Pakistan Journal of Agricultural Research, vol. 21, no. 1-4, pp. 92-97, 2008.

[24] R. D. Kale, Earthworm Cinderella of Organic Farming, Prism Book Pvt Ltd, Bangalore, India, 1998.

[25] A. A. Ansari and S. A. Ismail, "Paddy cultivation in sodic soils through vermitech," International Journal of Sustainable Crop Production, vol. 3, no. 5, 2008.

[26] M. Jaikumar, T. Sivakami, D. Ambika, and N. Karmegam, "Effect of turkey litter (Meleagris gallopavo L.) vermicompost on the growth and yield characteristics of paddy, Oryza sativa (ADT-37)," Africal Journal of Biotechnology, vol. 10, no. 68, pp. 15295-15304, 2011. 

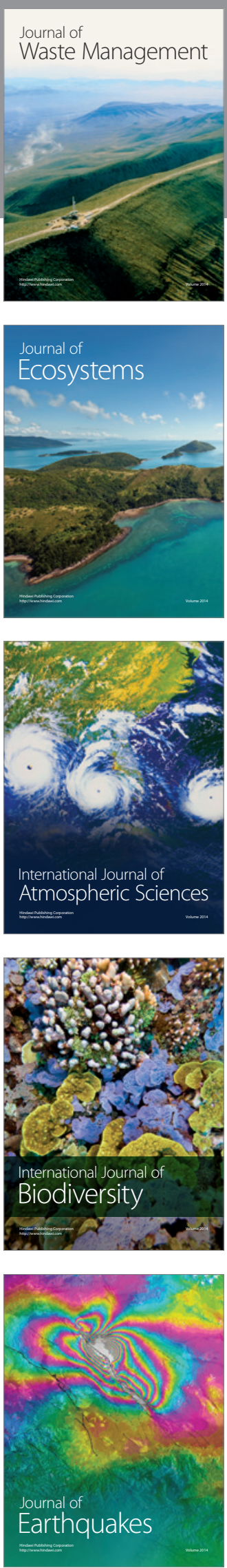
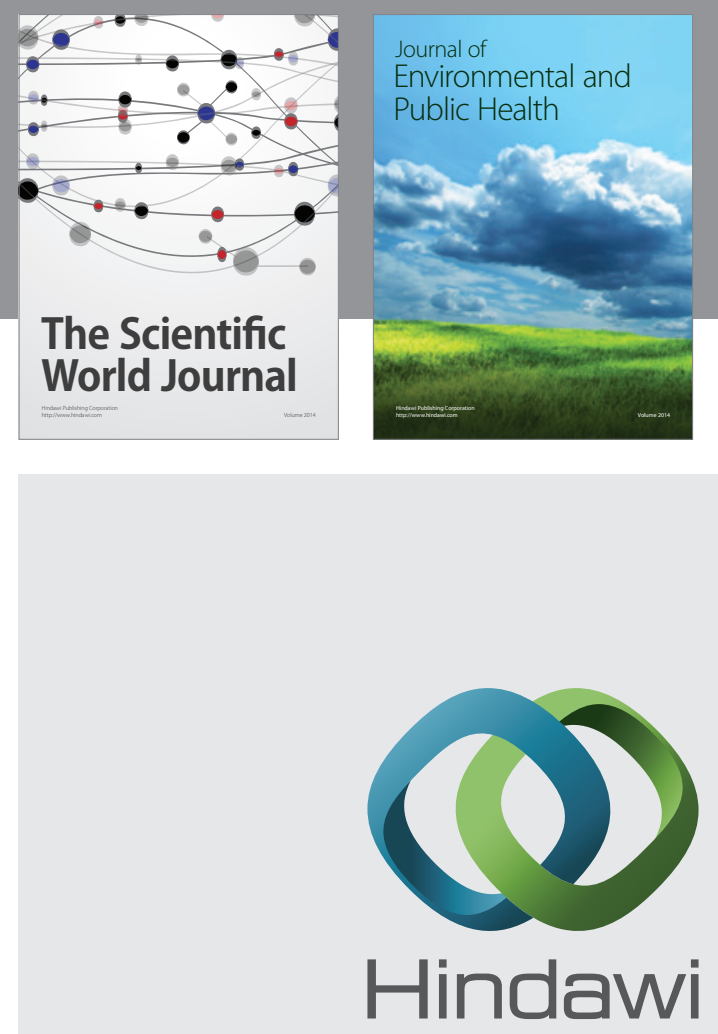

Submit your manuscripts at

http://www.hindawi.com
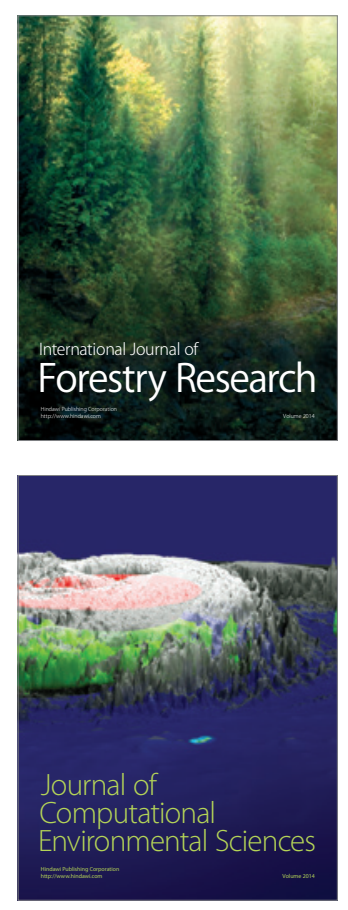
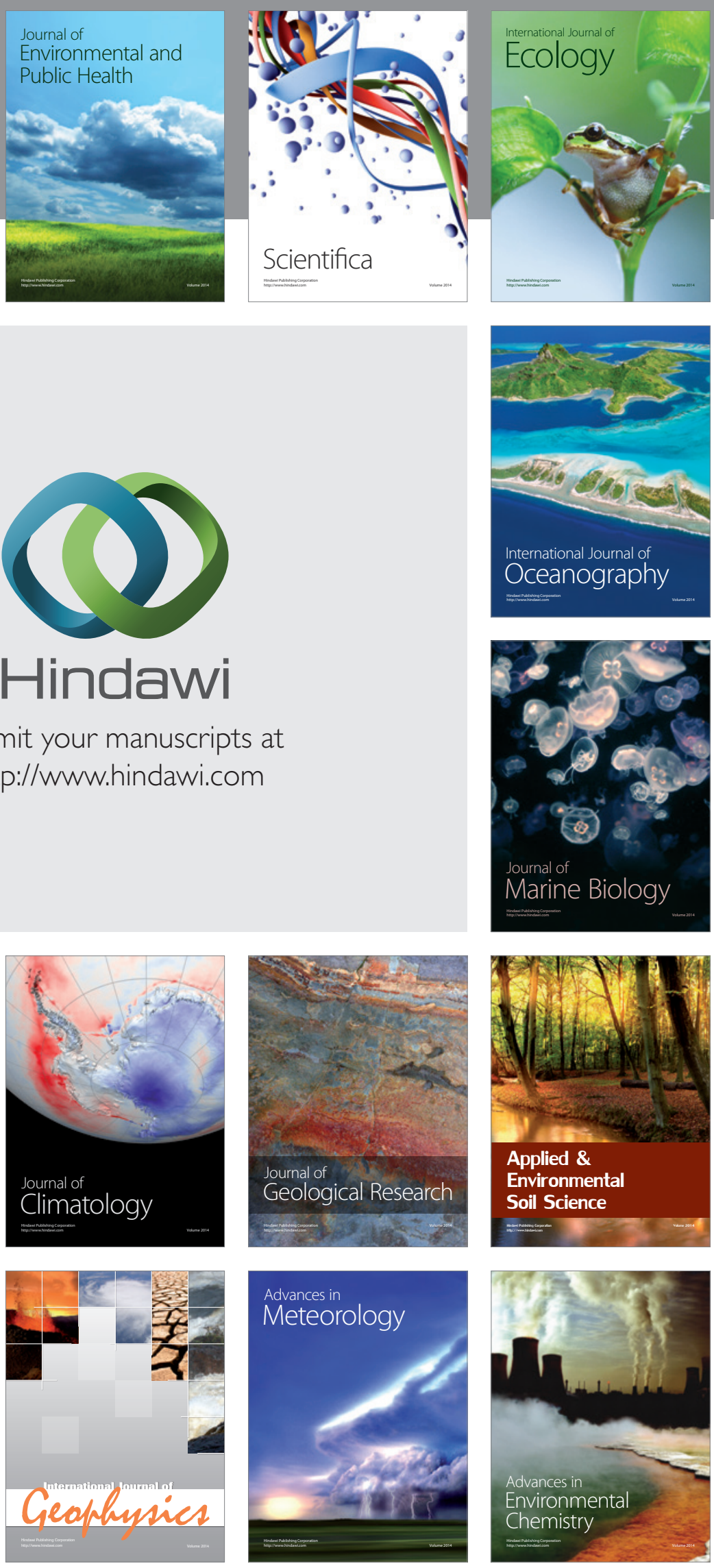